\title{
PLNĚ AUTOMATICKÉ ŘEŠENÍ PRO DETEKCI POVODNÍ Z DAT SENTINEL-1
}

\author{
Ivana HLAVÁČOVÁ ${ }^{1}$, Michal KAČMAŘíK ${ }^{1}$, Milan LAZECKÝ², Juraj STRUHÁR ${ }^{1}$, Petr RAPANT ${ }^{1}$ \\ ${ }^{1}$ Katedra geoinformatiky, Hornicko-geologická fakulta, VŠB - Technická univerzita Ostrava, 17. listopadu \\ 2172/15, 708 00, Ostrava, Česká republika \\ michal.kacmarik@vsb.cz \\ ${ }^{2}$ IT4Innovations národní superpočítačové centrum, VŠB - Technická univerzita Ostrava, 17. listopadu \\ 2172/15, 708 00, Ostrava, Česká republika \\ doi: https://doi.org/10.31490/9788024845081-121
}

\begin{abstract}
Abstrakt
Příspěvek slouží $k$ představení vyvinutého plně automatického řešení pro detekci povodní v blízkém reálném čase $z$ veřejně dostupných snímků družic Sentinel-1. Řešení umožňuje detekci otevřených vodních ploch vzniklých záplavami, je možné jej spustit pro vyžádané jednorázové zpracování a zejména v autonomním režimu umožňujícím automatický monitoring nad zadanou oblastí. Na základní úrovni je vyvinuté rešení založeno na kombinaci algoritmu pro detekci změny a algoritmu pro detekci otevřené vodní plochy, přičemž oba z nich používají snímky z obou polarizací (VH, VV). Předtím, než je hodnocené území označeno jako zaplavené, musí být $v$ obou polarizacích pozitivně identifikováno oběma uvedenými algoritmy. Tato kombinace čtyř různých výstupů pro celkovou detekci je nutná pro úspěšné potlačení výskytu falešně pozitivních detekcí, většinou vlivem zemědělských prací. Výstupy vyvinutého řešení byly validovány na pěti povodňových událostech na území České republiky, Německa, Rakouska a Itálie. Byla nalezena dobrá shoda mezi rozsahy zaplavení určenými z vyvinutého řešení a z referenčních datových sad odvozených z optických družicových snímků, avšak vyvinuté řešení obvykle poskytuje podhodnocené rozsahy záplav. Důvodů této situace je několik, mezi ty hlavní patří používané nastavení parametrů citlivosti detekce, které zajištuje téměř úplné potlačení výskytů falešně pozitivních událostí.
\end{abstract}

\section{Abstract}

In this paper, a fully automated solution for near real-time open water flood detection using publicly available Sentinel-1 imagery is presented. It is capable of one-off processing on demand and mainly of a fully autonomous monitoring above a given area of interest. On a fundamental level, the solution is based on a combination of change detection algorithm and open water detection algorithm while both of them are working in two polarizations ( $\mathrm{VH}, \mathrm{VV})$. In order for an evaluated area to be labelled as flooded, there must be a positive change detection in both polarizations and a positive open water detection in both polarizations. This setup combining four different inputs is necessary for a successful suppression of false positives, mostly due to agricultural works. The developed solution for open water floods detection was validated on five different flood events within the Czech Republic, Germany, Austria and Italy. A good agreement between extent of floods identified from the developed solution and from the reference datasets based on optical satellite imagery was found, however the developed solution usually provides a weakened detection of real floods. This can be attributed to several reasons, one of the main ones is the used settings of sensitivity parameters in the algorithm which ensures almost full suppression of false positive events.

\section{Klíčová slova: automatická detekce; povodně; Sentinel-1.}

\section{Keywords: automatic detection; floods; Sentinel-1.}

\section{ÚVOD}

V rámci programu Copernicus (https://www.copernicus.eu/cs) je provozována dvojice družic Sentinel-1 vybavených radarem se syntetickou aperturou (SAR - synthetic aperture radar) pracujícím s mikrovinným zářením a díky tomu schopným snímkovat zemský povrch $v$ kteroukoliv část dne za jakýchkoliv meteorologických podmínek. Radarová družicová měření jsou využívána v široké škále aplikací využívajících 
bud' hodnocení intenzity odrazu signálu a případně jeho změn $v$ čase či prostoru, nebo interferometrické techniky.

Cílem tohoto príspěvku je představit vyvinuté řešení umožňující plně automatické zpracování snímků pořízených družicemi Sentinel-1 za účelem detekce území zaplavených povodněmi. Toto řešení bylo vytvořeno v rámci projektu Earth Observation Automated Monitoring Open Platform v programu ESA Incubed (https://incubed.phi.esa.int/portfolio/cgi-satsight/). Úkolem týmu z Vysoké školy báňské - Technické univerzity Ostrava (VŠB-TUO) v tomto projektu je vyvinout automatická zpracování snímků z družic Sentinel1 pro celkem čtyři př́ípady užití:

- Detekce území zaplavených povodněmi,

- Detekce změn v ochranných pásmech kritické infrastruktury (detekce nelegálních staveb),

- Monitoring vertikálních pohybů pozemní infrastruktury,

- Monitoring nelineárních vertikálních pohybů infrastruktury nad podzemními zásobníky plynu.

Vývojem řešení a postupů pro automatickou detekci zaplavených území z radarových družicových dat se již zabývalo několik výzkumných týmů, napríklad Pulvirenti et al. (2011), Martinis et al. (2015) či Twele et al. (2016). Všechny zmíněné práce jsou zaměřené na detekci otevřené vodní plochy, někteří z autorů se však věnovali také možnostem detekce zaplavené vegetace (Pulvirenti et al. 2013, Pierdicca et al. 2013) či detekce povodní v urbánním prostředí (Giustarini et al. 2013). Otevřené vodní plochy se v radarových snímcích projevují velmi nízkými hodnotami intenzity odraženého signálu, což obvykle umožňuje jejich identifikaci a rozlišení od jiných typů krajinného pokryvu. S ohledem na informace uvedené v Pulvirenti et al. (2013) je však potřeba zmínit, že intenzita signálu odraženého od otevřených vodních ploch je kromě systémových parametrů použitého sensoru (vlnová délka, polarizace, incidenční úhel) závislá také na aktuálních meteorologických podmínkách (vítr, teploty pod bodem mrazu).

\section{POPIS VYVINUTÉHO ŘEŠENÍ}

Vyvinuté řešení využívá pro detekci zaplavených ploch statistickou detekci změny intenzity odraženého signálu a prahování intenzity, oba tyto algoritmy probíhají na georeferencovných intenzitních mapách po radiometrické a terénní korekci, a po prostorové filtraci Lee filtrem (dále jen snímek). Jak detekce změn, tak prahování intenzity probíhá samostatně pro VV a VH polarizaci. Snímky nejsou koregistrovány, přesnost jejich překryvu je tedy $v$ řádu pixelu.

Statistická detekce změn intenzity porovnává aktuální snímek s průměrem několika (cca 5 , odpovídají cca měsíci dat) snímků minulých, nasnímaných ve stejném tracku a majících tedy stejné odrazivé vlastnosti (dále jen referenční dataset). Pro každý pixel snímku se provádí test statistické významnosti rozdílu mezi průměrem referenčního datasetu a aktuálního snímku $s$ tím, že výsledkem tohoto testu je reálné číslo (mapa), kde znaménko odpovídá znaménku změny intenzity (pokles či nárůst) $a \pm 1$ odpovídá mezi statistické významnosti. Tato mapa (její absolutní hodnota) se pak srovnává se dvěma předdefinovanými fuzzy prahy a výsledkem je fuzzy mapa změny.

Detekce otevřených vodních ploch se provádí prahováním samotné intenzity. Implementace je inspirována zdroji Martinis et al. (2015) a Twele et al. (2016): práh je třeba určit nezávisle pro každý snímek. Vyhledávání minima bimodálního histogramu se ukázalo jako velmi chybové, protože bimodální histogramy často vznikají na zemědělských plochách $v$ obdobích častých zemědělských prací, a navíc by nereflektovalo prípad malé zatopené plochy ve velké oblasti zájmu (area of interest, $\mathrm{AOI}$ ), kde by se bimodální histogram nezformoval. Toto platí i pro prípad, kdy se histogram tvoři pouze z pixelů, u nichž byla dríve detekována změna (tento algoritmus je součástí řešení, avšak detekce zaplavených ploch je takto méně spolehlivá).

Intenzitní prahy se proto $v$ řešení primárně určuji jejich odečtem ze stálých vodních ploch. Předpokládá se, že tyto stálé vodní plochy jsou $v$ blízkosti sledovaného území (a panují na nich stejné meteorologické podmínky, které mají vliv na intenzitu radarového obrazu). Jako jejich zdroj je možno využít volně dostupné i celosvětové polygony vodních ploch, je vhodné však zkontrolovat jejich kvalitu, a v př́ípadě, že pokrývají z výrazné části i břehovou plochu, tyto polygony zmenšit. $Z$ histogramu intenzity na těchto vodních plochách (všechny vodní plochy dohromady) se odečitá maximum a cca $85 \%$ kvantil (15 \% bodů s nejvyšší intenzitou 

se ignoruje jako možné chyby) - jako dva fuzzy prahy pro vytvoření fuzzy mapy detekce otevřené vodní plochy.

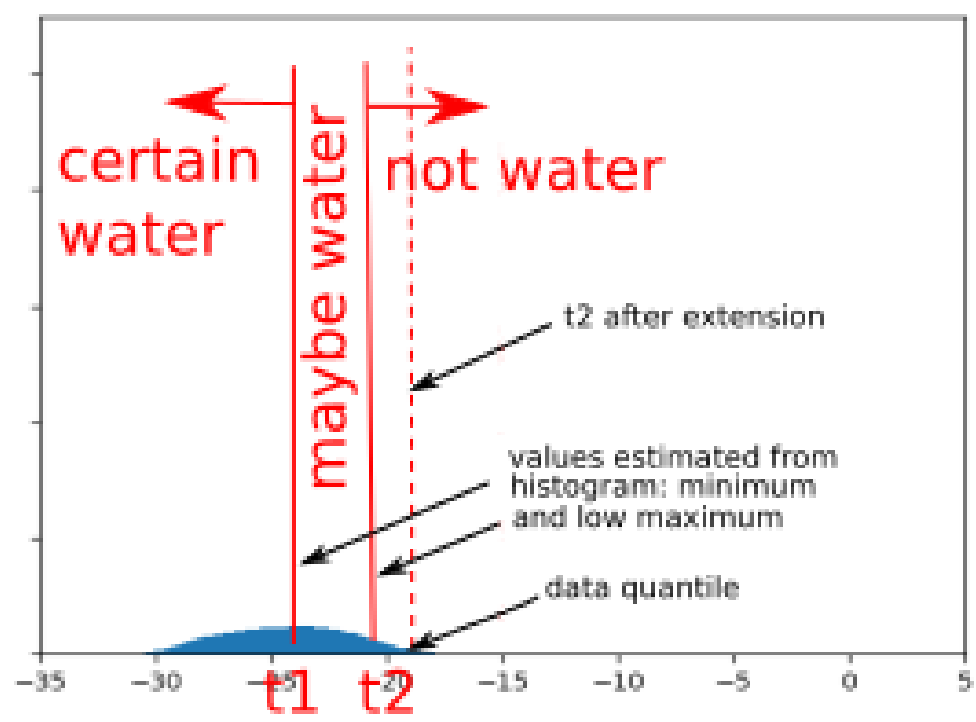

Obr. 2. Ilustrace výběru a pozdější úpravy fuzzy prahů pro detekci otevřené vody.

Pokud je vyšší z těchto prahů vyšší než určitá konstanta, pravděpodobně nejde o vodu, nebo je vlivem silného větru a tudíž možného vzniku vln zvýšena intenzita odrazu, detekce povodní není možné provést (dle provedených testování tento případ nastává na vybrané oblasti cca 1x-2x ročně). Tyto dva "surové" prahy jsou následně upravovány, aby byla detekce povodní spolehlivá.

$\mathrm{Na}$ všech čtyřech vzniklých fuzzy mapách (mapa změn, mapa otevřené vody, obě pro VV i VH polarizaci) následně probíhá region-growing (Twele et al, 2016) za účelem odfiltrování šumu a nastolení prostorové spojitosti. Takto upravené mezi výstupy jsou následně zkombinovány do fuzzy mapy zaplavené plochy, a to samostatně pro VH a VV polarizaci. Fuzzy kombinace se provádí dle (Martinis et al, 2015).

Při detekci zaplavených ploch pouze z jedné polarizace dochází k výskytu falešně pozitivních případů, a to obvykle na jaře (pro VV polarizaci) a na podzim (pro VH polarizaci), pravděpodobně vlivem zemědělských prací, případně vlivem růstu vegetace na polích. $Z$ tohoto důvodu v závěru zpracování dochází ještě $\mathrm{k}$ fuzzy kombinaci map zaplavených ploch pro obě polarizace, což snižuje počet falešně pozitivních případů na minimum. Dále je vhodné zmínit, že řešení vykazuje detekci povodní jako pozitivní pouze v př́padě, že dojde $\mathrm{k}$ detekci na alespoň $0,1 \%$ pixelů zadané $\mathrm{AOI}$

Algoritmus funguje $v$ trvalém režimu zpracování, jeho součástí je tedy pravidelné testování na přitomnost nového snímku na serveru ESA a jeho testování oproti dříve nasnímaným snímkům. Snímky, které byly označeny jako povodňové, a snímky, kde povodně nelze detekovat vlivem nevhodných meteorologických podmínek (viz výše), se nepřidávají do referenčního datasetu. Vyvinuté řešení zpracovává nezávisle na sobě data ze dvou až čtyř družicových drah pokrývajících zadanou oblast (v závislosti na velikosti oblasti a jejím pokrytí). Výsledky z jednotlivých drah jsou tedy na sobě nezávislé a liší se datem pořízení snímku.

\section{VALIDACE VYTVOŘENÉHO ŘEŠENÍ}

Vyvinuté řešení bylo validováno s využitím celkem pěti povodňových událostí, které se staly v letech 2017 až 2020 na území České republiky, Německa, Rakouska či Itálie. Většinou jednalo o dlouhodobější povodně $\mathrm{s}$ rozlivy vodních toků $v$ přírodní krajině, tedy o charakter událostí, pro které je vyvinuté řešení primárně určeno. Testovány však byly také schopnosti vyvinutého řešení detekovat silné bleskové povodně či detekovat zaplavení v urbánním prostředí. Postup validací vycházel z následujících kroků:

1) Zpracování dat $z$ déletrvajícího časového období (obvykle březen až listopad) $z$ alespoň dvou dostupných tracků, 
2) Celkové zhodnocení výsledků zpracování $v$ průběhu celého časového období, tedy zejména zhodnocení detekce povodní v korektních termínech a výskytu falešně pozitivních detekcí,

3) Detailní zhodnocení kvality detekce skutečných povodní, kdy byl rozsah detekovaných povodní porovnán s referenční datovou sadou odvozenou z optických družicových snímků, z vlastní dokumentace rozsahu povodní na dané lokalitě či z jiného zdroje.

$\checkmark$ rámci tohoto príspěvku je $v$ následujícím textu uvedeno pouze shrnutí zjištěných výsledků charakterizující schopnosti a limity vytvořeného řešení a níže jsou umístěny dvě ukázky grafických výstupů realizované validace.

Povodně byly úspěšně detekovány ve čtyřech z pěti validovaných událostí. Byla nalezena dobrá shoda mezi rozsahy záplav identifikovanými vytvořeným řešením a odvozenými z referenčních datových zdrojů. $V$ tomto ohledu je však nutné uvést, že vytvořené řešení obvykle poskytovalo slabší rozsahy záplav, kdy detekované polygony byly menší velikosti či $v$ některých prípadech zcela chyběly. Tato situace je zejména priičitána realizované optimalizaci sady parametrů definujících v řešení citlivost detekce. Zvýšení citlivosti detekce sice vedlo ke zlepšení výsledků detekce reálných povodní, na druhou stranu však způsobovalo zvýšení výskytu nežádoucích falešně pozitivních detekcí.

Silné bleskové povodně, které postihly na začátku června roku 2020 okolí města Uničova, nebyly vytvořeným řešením detekovány při použití finálně zvoleného nastavení parametrů citlivosti detekce, a to ani v místech vzniku dočasně zaplavených lagun. Ačkoliv byly tyto plochy korektně označeny jako zaplavené algoritmem sloužícím pro identifikaci otevřených vodních ploch (viz popis výše), celkové detekci povodně zabránilo nedetekování změny v odrazivosti povrchu na daných plochách oproti stavu před povodní. Ve všech prípadech se jednalo o zemědělská pole s počínajícím růstem plodin, zaplavením povrchu tedy nedošlo k výrazné změně v jeho odrazivosti oproti předchozímu stavu.

Při zpracování dat z déletrvajícího časového období (obvykle jaro až podzim) docházelo ve všech zpracovaných oblastech knulovému či minimálnímu výskytu falešně pozitivních detekcí povodní, tedy k falešnému označení ploch za zaplavené, i když na nich $v$ daném čase k prokázaným záplavám nedošlo. Všechny z nich byly identifikovány $v$ jarním období mezi koncem března a koncem května a většina z nich se nacházela na zemědělsky využívaných plochách. Jejich původ je tedy velice pravděpodobně spojen se zemědělskými pracemi realizovanými na začátku vegetačního období. $V$ tomto ohledu je vhodné pripomenout, že vyvinuté řešení nepoužívá žádná prìidružená data, která by mohla dále pomoci s potlačením vzniku falešně pozitivních detekcí. Jednou z možností by $v$ tomto ohledu mohla být například dodatečná implementace topograficky-hydrologického faktoru HAND (height above nearest drainage), viz práce Nobre et al. (2011).

\section{LIMITY VYTVOŘENÉHO ŘEŠENÍ, ZÁVĚR}

Vyvinuté řešení je schopné detekovat pouze pixely příslušející otevřené vodě, s ohledem na střední rozlišení družic Sentinel-1 pouze mimo zástavbu. Pro účely prípadné cílené detekce bleskových povodní je možno samostatně použít mapy změn, nelze však na nich rozlišit povodňové změny od změn jiných vznikajících nejčastěji z důvodu zemědělských prací. Kromě již dřive popsaného vlivu nastavení parametrů ovlivňujících citlivost detekce změn a zaplavených ploch se kvalita detekce odvijí mimo jiné od kvality vymezení stálých vodních ploch.

Vyvinuté řešení bude implementováno do platformy SatSight vyvíjené společností CGI IT Czech Republic v rámci projektu Earth Observation Automated Monitoring Open Platform a díky tomu bude operativně sloužit klientům této společnosti $\mathrm{k}$ detekci povodní nad jejich oblastmi zájmu. 


\section{FLOOD DETECTION IN AREA 11, GERMANY 2017}

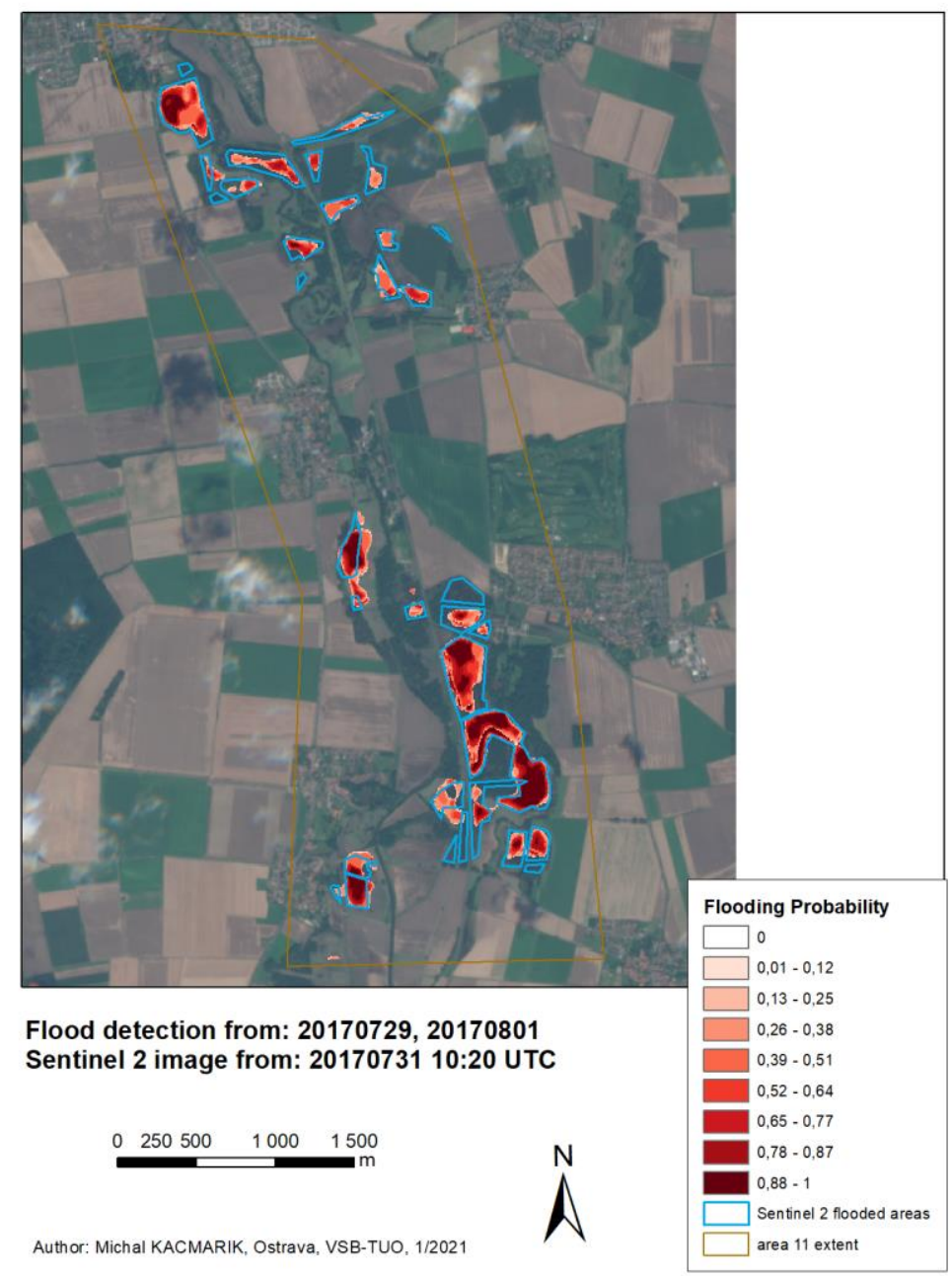

Obr. 2. Rozsah záplavy ve vybrané oblasti v Německu detekované vytvořeným řešením ze snímků Sentinel1 pořízených 29. 7. a 1. 8. 2017 (odstíny červené) a odvozené manuální digitalizací z družicového snímku Sentinel-2 pořízeného 31. 7. 2017 (modré polygony). 


\section{FLOOD DETECTION IN SUB-AREA 1, THE CZECH REPUBLIC, AUTUMN 2020}

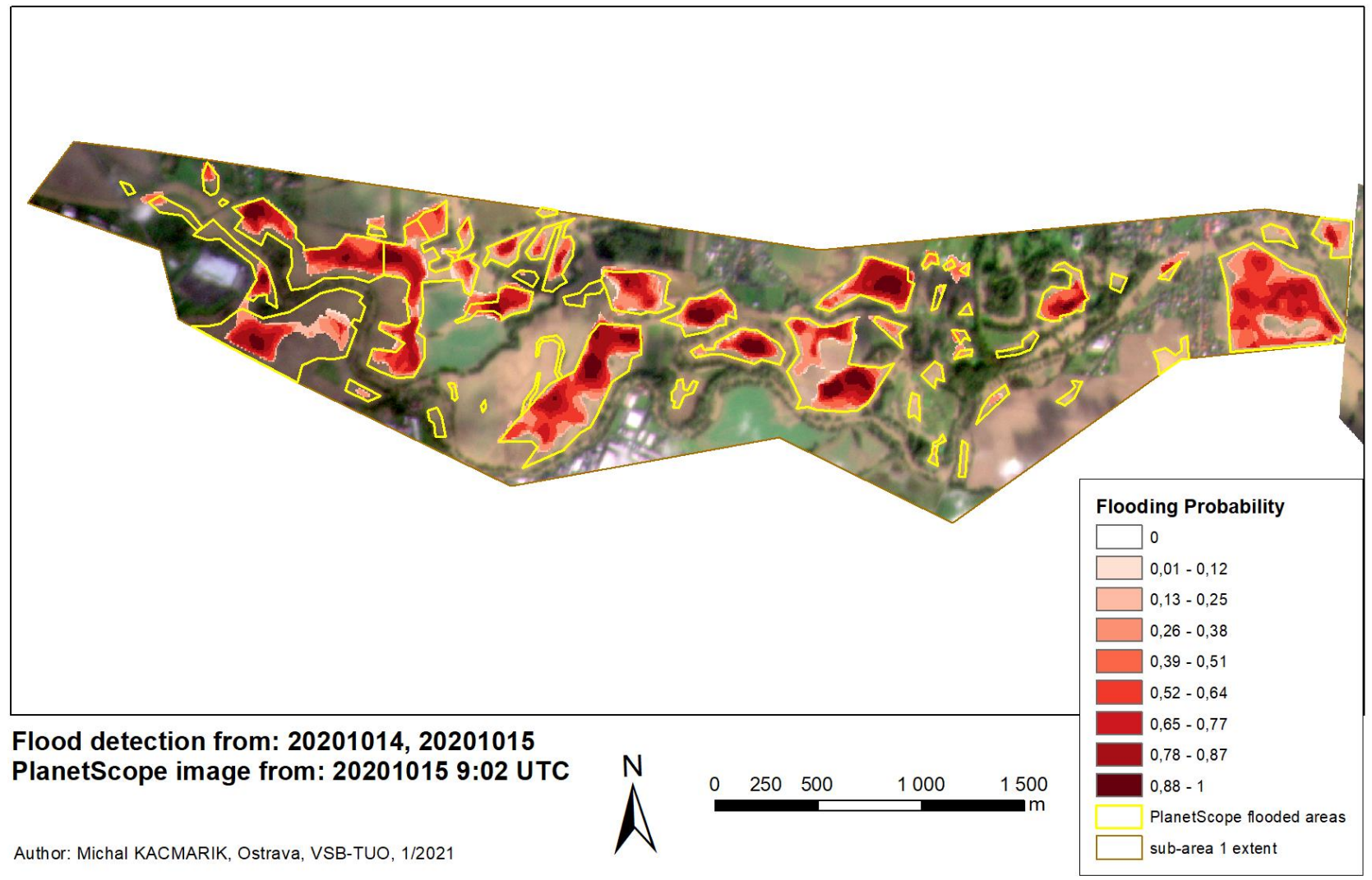

Obr. 3. Rozsah záplavy v okolí města Opavy detekované vytvořeným řešením ze snímků Sentinel-1 pořízených 14. a 15. 10. 2020 (odstíny červené) a odvozené manuální digitalizací z družicového snímku

PlanetScope pořízeného 15. 10. 2020 (žluté polygony).

\section{LITERATURA}

Giustarini, L., Hostache, R., Matgen, P., Schumann, G.J., Bates, P.D., Mason, D.C. (2013) A Change Detection Approach to Flood Mapping in Urban Areas Using TerraSAR-X. IEEE Transactions on Geoscience and Remote Sensing, 51, 4, 2417-2430, doi: 10.1109/TGRS.2012.2210901.

Martinis, S., Kersten, J., Twele, A. (2015) A fully automated TerraSAR-X based flood service. ISPRS J. Photogramm. Remote Sens., 104, 203-212.

Nobre, A.D., Cuartas, L.A., Hodnett, M., Rennó, C.D., Rodrigues, G., Silveira, A., Waterloo, M., Saleska, S. (2011) Height Above the Nearest Drainage - a hydrologically relevant new terrain model. Journal of Hydrology, 404, 1-2, doi:10.1016/j.jhydrol.2011.03.051.

Pierdicca, N., Pulvirentia, L., Chinib, M., Guerrieroc, L., Candelad, L. (2013) Observing floods from space: Experience gained from COSMO-SkyMed observations. Acta Astronautica, 84.

Pulvirenti, L., Pierdicca, N., Chini, M., Guerriero, L. (2011) An algorithm for operational flood mapping from Synthetic Aperture Radar (SAR) data based on the fuzzy logic. Nat. Hazards Earth Syst. Sci., 11, 529-540, doi:10.5194/nhess-11-529-2011.

Pulvirenti, L., Pierdicca, N., Chini, M., Guerriero, L. (2013) Monitoring Flood Evolution in Vegetated Areas Using COSMO-SkyMed Data: The Tuscany 2009 Case Study. IEEE Journal of Selected Topics in Applied Earth Observations and Remote Sensing, 6, 4, 1807-1816, doi:10.1109/JSTARS.2012.2219509. 

Twele, A., Cao, W., Plank, S., Martinis, S. (2016) Sentinel-1-based flood mapping: a fully automated processing chain. International Journal of Remote Sensing, 37, 13, 2990-3004, 2016, doi: 10.1080/01431161.2016.1192304. 